\title{
Proposed model to study the economic impact of bovine brucellosis and tuberculosis: Case study of Pirassununga, SP, Brazil
}

\section{Proposta de modelo para estudo do impacto econômico da brucelose e tuberculose bovinas: Caso de Pirassununga, SP, Brasil}

\author{
Valéria Stacchini Ferreira Homem ${ }^{*}$; Zenaide Maria de Morais Higa'; \\ José Soares Ferreira Neto ${ }^{3}$
}

\begin{abstract}
Following the recent implementation of the National Program for the Control and Eradication of Brucellosis and Tuberculosis (PNCEBT), and the lack of economic research on animal health in Brazil, we created a model to estimate the economic impact of brucellosis and tuberculosis on livestock production, using the municipality of Pirassununga/SP as a case study. The first part of our study consisted of a literature review of the estimates of losses caused by the two diseases. The impact on production was converted into economic losses, also represented by monetary values, using secondary references from 2003. The losses were calculated for the entire municipality and took into account the actual prevalence of disease in the animals, and the type of disease in each of the affected properties. The results revealed the annual losses in Pirassununga, which, at the time of the study, were as high as $\mathrm{R} \$ 132,676.23$ for brucellosis (updated value by the IGP-M: R $\$ 273,407.43$ ), and between $\mathrm{R} \$$ $192,500.00$ and R \$ 430,252.00 for tuberculosis (values updated by the IGP-M: R \$ 396,686.97 and R\$ $886,825.25)$. These results suggest that these diseases had a significant impact on livestock production in the municipality of Pirassununga. The impacts they have on agriculture, and the economy, should be rapidly be communicated throughout Brazil because this information will significantly improve the management of veterinary sanitary processes.
\end{abstract}

Key words: Brucellosis. Tuberculosis. Bovine. PNCEBT. Economic impact.

\section{Resumo}

Tendo em vista a implementação do Programa Nacional de Controle e Erradicação da Brucelose e Tuberculose (PNCEBT) e a carência de investigações econômicas sobre saúde animal no Brasil, o presente estudo teve por objetivo propor um modelo para estimar o impacto econômico dessas doenças em função das perdas anuais esperadas na produção pecuária, usando como exemplo o município de Pirassununga/SP. A primeira etapa do estudo consistiu em pesquisar na literatura estimativas dos prejuízos causados pelas duas doenças. O impacto produtivo foi convertido em impacto econômico, representado por valores monetários, usando referencias secundárias pesquisadas em 2003. As perdas foram calculadas para todo o município considerando-se as prevalências reais de animais e a tipologia de propriedades acometidas. Os resultados estimaram as perdas anuais em Pirassununga, à época do estudo, em valores de até R $\$ 132.676,23$ para a brucelose (Valor atualizado pelo IGP-M: $\mathrm{R} \$ 273.407,43$ ), e entre $\mathrm{R} \$ 192.500,00$ e $\mathrm{R} \$ 430.252,00$ para a tuberculose (Valores atualizados pelo IGP-M: R \$396.686,97 e R \$886.825,25). Esses resultados indicam que estas doenças tiveram impacto significativo na produção pecuária do munícipio. A área de economia em saúde animal deveria se difundir rapidamente no ambiente brasileiro, pois melhora significativamente a gestão dos processos sanitários na área veterinária.

Palavras-chave: Brucelose. Tuberculose. Bovinos. PNCEBT. Impacto econômico.

\footnotetext{
1 Pesquisadora, Ministério da Agricultura, Pecuária e Abastecimento, Brasília, DF, Brasil. E-mail: valeria.homem@agricultura. gov.br

2 Pesquisadora, Faculdade de Medicina Veterinária e Zootecnia, Universidade de São Paulo, USP, São Paulo, SP, Brasil. E-mail: zenaide@usp.br

3 Prof., Faculdade de Medicina Veterinária e Zootecnia, USP, São Paulo, SP, Brasil. E-mail: jsoares@vps.fmvZ.usp.br

* Author for correspondence
} 


\section{Introduction}

Bovine brucellosis and bovine tuberculosis are two potentially economically devastating diseases common throughout Brazil. Caused by the Brucella abortus bacterium, brucellosis affects both cattle well-being and milk production. Tuberculosis, in contrast, is caused by the Mycobacterium bovis bacterium, and often affects dairy herds, especially those in which technification is used for production. Both these diseases can also affect buffalo populations.

Breakouts of both diseases result in significant losses in the productivity of herds (ACHA; SZYFRES, 2001). Specifically, they jeopardize milk and meat production, as well as causing losses of prestigious herds. Furthermore, they their products may become subject to trade restrictions due to health concerns, decreasing competitiveness and thus affecting international trade (PAULIM; FERREIRA NETO, 2003). Since both diseases are zoonotic, they also pose a significant health risk to the public.

In 2001, Brazil's Ministry of Agriculture, Livestock and Supply (MAPA), having decided that existing eradication programs were inefficient as published on Ministerial Publication 23/1976 (BRASIL, 1976); and specifically on Articles 483, 485 and 486 of RIISPOA (BRASIL, 1952), implemented a new program, called the National Program for the Control and Eradication of Brucellosis and Tuberculosis - PNCEBT (BRASIL, 2001). The intention was for the program not to appear as an isolated operation, but rather a mechanism that contributes to the improvement of infrastructure, the economy and the promotion of rural development in Brazil, in accordance with ideals of the WORLD HEALTH ORGANIZATION (WHO, 1982).

Economic studies have become integral to the decision-making process of health programs (MARTIN et al., 1994; THRUSFIELD, 1995). They should be viewed as a means by which to provide additional information to assist with decisionmaking, but should not constitute an isolated or definitive process (MARTIN et al., 1994).

While the damage to dairy production resulting from brucellosis and tuberculosis varies according to the incidence and severity of the two diseases, assessing their impacts is complex. Their effects are not always obvious. Furthermore, they can be influenced by several factors, such as management practices and environmental cues, among others. There is also a temporal dimension to them, further complicating the assessment process over time. The fact the two diseases rarely occur on their own, and usually manifest during outbreaks of other diseases, is yet another factor to be considered (NGATEGIZE; KANEENE, 1985). Despite M. bovis and B. abortus also infecting and harming humans, and thus also affecting the economy owing to loss of work and health-related expenses, these costs are rarely considered (HUGH-JONES et al., 1975 apud BENNETT, 1992). Most studies into the economic impact of bovine brucellosis and tuberculosis have focused primarily on animal populations.

In spite of the benefits of economic analysis of sanitary processes affecting animal populations, Brazil has a poor track record in conducting studies of this type. This has traditionally deprived decision makers of important information about the cost of the two diseases and their control programs. This present study therefore aimed to develop a methodology for the evaluation of the economic impact of bovine brucellosis and tuberculosis, using the municipality of Pirassununga, SP, as a case study.

The municipality of Pirassununga occupies an area of $727 \mathrm{~km}^{2}$ and has a population of approximately 75 thousand inhabitants. It is located in a hub of intense socioeconomic development between the cities of São Paulo and Ribeirão Preto, in the state of São Paulo. It is located 207 $\mathrm{km}$ kilometers north of the state capital, (IBGE, 2010). It was also chosen because the University 
of São Paulo (USP), with its School of Veterinary Medicine and Zootechny, is located there.

In 2001, according to the Agriculture House database and the IBGE (1999), Pirassununga had a herd of approximately 16,700 head of cattle, of which 3,500 were dairy cows for the production of type B (150,000 liters per year) and type C $(2,000,000$ liters per year) milk. In addition to a study by Melo (1999), data from a routine diagnosis service performed by the FMVZ-USP confirmed the presence of both bovine tuberculosis and bovine brucellosis in the municipality.

Another study performed in Pirassununga in 2001 revealed there was an 18.6\% [95\% CI: 11.0; 28.4] prevalence of outbreaks and 1.1\% [95\% CI: 0; 2.1] of animals with brucellosis. For tuberculosis, these data were $55.8 \%$ [95\% CI: 44.7; 66.5] and $8.9 \%$ [95\% CI: 5.5; 12.3], respectively. The prevalence of concomitant foci was $16.3 \%$ [95\% CI: 9.2; 25.8] (HOMEM, 2003).

\section{Materials and Methods}

The first part of this study consisted of a literature review, looking for estimates of losses caused by both brucellosis and tuberculosis, i.e., when cattle affected by these diseases will cease to produce because of the infections. The impact on production was converted into financial impact, based on studies conducted in 2003. Losses were calculated for the entire municipality, taking into account the prevalence of disease in livestock and information obtained from a database created from questionnaires that were answered by the producers
(HOMEM, 2003). Our calculations were based on a herd of 16,700 animals (IBGE, 2001), which were located in 750 properties (Levantamento Censitário das Unidades de Produção Agropecuária do Estado de São Paulo - L.U.P.A., 1995-96 (SÃO PAULO, 1996). It included records of vaccination against foot and mouth disease of the local Agriculture House. The proportion of cows to bulls, the mean age, and the predominant racial pattern were also extracted from the database created by Homem (2003).

The prevalence of disease in the animals was multiplied by the size of the herd, yielding the number of infected animals. Using the same database, which included positive and negative results for the animals, as well as the final result by herd, it was possible to determine the productive data of infected versus non-infected properties for both diseases. Thus, losses reported in the literature were cross-checked with productive data for the infected groups, estimating the losses determined by the drop in production. These losses were converted into annual economic impact for each disease. Finally, productive data were expressed in monetary values, reflecting market prices at the time.

\section{Results}

The losses associated with the presence of bovine brucellosis and tuberculosis were estimated from data reported in the literature (Table 1). Table 2 shows the values used for conversion of the productive impact into financial impact, based on the literature review. 
Table 1. Losses caused by bovine tuberculosis and brucellosis.

\begin{tabular}{|c|c|c|}
\hline Type of loss & $\begin{array}{c}\text { Drop in } \\
\text { production }\end{array}$ & Source \\
\hline \multicolumn{3}{|l|}{ Brucellosis } \\
\hline Reduction in milk production & $25 \%$ & $\begin{array}{l}\text { (HUGH-JONES et al., } 1975^{1} \text {; CARPENTER, } \\
\text { 1976'; SHEPERD et al., } 1982^{3} \text {; GOMEZ, } \\
\text { 1986'; MURILLO, } 1989^{5} \text { ) apud Bernués et al. } \\
\text { (1997); Paulin and Ferreira Neto, }(2003)\end{array}$ \\
\hline Reduction in food conversion & $10 \%$ & Paulin; Ferreira Neto (2003) \\
\hline Abortion among infected cows & $15 \%$ & $\begin{array}{l}\text { Bernués et al. (1997); Paulin and Ferreira Neto } \\
\text { (2003) }\end{array}$ \\
\hline Infertility in cows that aborted & $20 \%$ & $\begin{array}{l}\text { (HUGH-JONES et al., } 1975^{1} \text {, GOMEZ, 1986'; } \\
\text { MURILLO, 19895) apud Bernués et al. (1997) }\end{array}$ \\
\hline Perinatal death of calves born from infected cows & $15 \%$ & $\begin{array}{l}\text { (HUGH-JONES et al., } 1975^{1} \text {; GOMEZ, 1986'; } \\
\text { MURILLO, 19895) apud Bernués et al. (1997) }\end{array}$ \\
\hline Dilation of calving interval in infected cows & 14 to 20 months & $\begin{array}{l}\text { Hoedemaker (1997); Paulin; Ferreira Neto } \\
(2003)\end{array}$ \\
\hline Mortality of cows that aborted & $1 \%$ & Gomez $\left(1986^{4}\right)$ apud Bernués et al. (1997) \\
\hline \multicolumn{3}{|l|}{ Tuberculosis } \\
\hline Reduction in milk production & $18 \%$ & $\begin{array}{l}\text { Barwinek and Taylor (1996); Nader, Husberg } \\
\left(1988^{6}\right) \text { apud Kantor and Ritacco (1994) p.6 }\end{array}$ \\
\hline Reduction in food conversion & $20 \%$ & Barwinek and Taylor (1996) \\
\hline Reduction in births & $5 \%$ & $\begin{array}{l}\text { Barwineka and Taylor (1996); Bernués et al. } \\
\text { (1997) }\end{array}$ \\
\hline Perinatal death of calves & $1 \%$ & Barwinek and Taylor (1996) \\
\hline
\end{tabular}

1: HUGH-JONES, M. E.; ELLIS, P. R.; FELTON, M. R. An assessment of the eradication of bovine brucellosis in England and Wales. University of Reading, Department of Agriculture and Horticulture, 1975. 75 p. (Estudo n. 19).

2: CARPENTER, T. E. The application of benefit-cost analysis to compare alternative approaches to the brucellosis problem in California. In: New Techniques in veterinary epidemiology and economics. Reading, 1976.

3: SHEPERD, A. A.; SIMPSON, B. H.; DAVIDSON, R. M. An economic evaluation of the New Zealand bovine brucellosis eradication scheme. Technical Series OIE, v. 3, p. 69-78, 1982.

4:GÓMEZ, J. La brucellosis em la ganaderia de Almeria. In: Primeras Jornadas sobre Brucelosis, Colegio Oficial de Veterinários de Almeria, Almeria, 1986.

5: MURILLO, M. J. La Brucelosis en la provincia de Huesca: estado actual y repercusión econômica. Colección de Estúdios Altoaragoneses, Instituto de Estúdios Altoaragoneses, Huesca, 1989. 190 p.

6: NADER, A.; HUSBERG, H. Estimación de perdidas de producción por tuberculosis bovina en un rodeo lechero. Revista de Medicina Veterinaria de Buenos Aires, v. 69, p. 36-43, 1988.

Table 2. References used for the conversion of the impact on production into financial impact.

\begin{tabular}{lcl}
\hline \multicolumn{1}{c}{ Goods or Service } & Value $(\boldsymbol{R} \$)$ & \multicolumn{1}{c}{ Source $^{1}$} \\
\hline Calf in the State of São Paulo (ESP) & 260.00 & $\mathrm{http}: / /$ www.beefpoint.com.br \\
300kg mestizo cow in the ESP & 391.00 & $\mathrm{http}: /$ www.beefpoint.com.br \\
330kg mestizo bull in the ESP & 559.00 & $\mathrm{http}: / /$ www.beefpoint.com.br \\
Liter of type C milk & 0.50 & $\mathrm{http} / /$ www.milkpoint.com.br \\
\hline
\end{tabular}

${ }^{1}$ available online; accessed on $08 / 25 / 2003$. 
Estimates of the impact for each of the diseases on the production of the herds were based on the respective confidence intervals (CI) for the real prevalence of disease in the animals, as described by Homem (2003). The productive impact was converted into economic impact, and was expressed as a financial loss (NGATEGIZE; KANEENE, 1985). Both the variables and respective values used for the calculation of the economic and productive impact of brucellosis are presented in Tables 3 and 4, while those for tuberculosis can be found in Tables 5 and 6 .

Table 3. Prevalence of bovine brucellosis for the municipality of Pirassununga in 2001, as according to HOMEM (2003).

\begin{tabular}{lcc}
\hline \multicolumn{1}{c}{ Actual prevalence } & Lower limit CI & Upper limit CI \\
\hline PER PROPERTY & & 28.4 \\
percentage & 11 & 213 \\
absolute number & 83 & 2.2 \\
PER ANIMAL & & 367 \\
percentage & 0 & 356 \\
absolute number & 0 & 11 \\
number of cows $(97 \%)^{1}$ & 0 & 0 \\
number of bulls $(3 \%)^{2}$ & 0 & \\
\hline
\end{tabular}

${ }^{1}$ average age of positive cows $=6$ years and 6 months .

${ }^{2}$ average age of positive bulls $=3$ years.

Table 4. Impact on production and respective losses arising from the infection of cattle by brucellosis in Pirassununga in 2003 .

\begin{tabular}{|c|c|c|}
\hline Variable & Value & Reference \\
\hline \multicolumn{3}{|l|}{ MILK } \\
\hline Average daily production (liters)/number of cows of positive herd & 2.9 & Database \\
\hline $\begin{array}{l}\text { Estimate of average daily production (liters)/number of cows of } \\
\text { supposed negative herd }\end{array}$ & 3.9 & Table 1 \\
\hline Price/liter of milk C $(\mathrm{R} \$)$ & 0.50 & http://www.milkpoint.com.br ${ }^{1}$ \\
\hline Liters of milk/cow/year lost & 365 & \\
\hline Loss/cow/year (R\$) & 182.50 & \\
\hline \multicolumn{3}{|l|}{ MEAT } \\
\hline \multicolumn{3}{|l|}{ Estimate of the weight of the bovine carcass by sex and age: } \\
\hline 3 year-old mestizo bull (in arrobas*) & 15 & Verbal information $^{2}$ \\
\hline 6.5 year-old mestizo cow (in arrobas*) & 14 & Verbal information ${ }^{2}$ \\
\hline \multicolumn{3}{|l|}{ Estimate of the price of beef by sex and age: } \\
\hline 3 year-old mestizo bull $(\mathrm{R} \$)$ & 45.00 & http://www.beefpoint.com.br ${ }^{1.3}$ \\
\hline 6.5 year-old mestizo cow $(\mathrm{R} \$)$ & 35.00 & http://www.beefpoint.com.br ${ }^{1.3}$ \\
\hline \multicolumn{3}{|l|}{ Weight loss in arrobas* due to infection } \\
\hline Bull & 1.53 & Table 1 \\
\hline Cow & 1.4 & Table 1 \\
\hline Loss/bull/year (R\$) & 69.00 & \\
\hline Loss/cow/year (R\$) & 49.00 & \\
\hline
\end{tabular}


continuation

\section{FERTILITY}

Average price of male and female calf (R\$)

Number of cows that miscarried

260.00

$0-53.4$

$0-53.4$

Calves lost to abortion in 14 months

Calves lost to abortion in 12 months

Annual loss of calves to abortion (R\$)

Number of cows which become infertile after abortion

Calves lost to infertility in 14 months

Calves lost to infertility in 12 months

\section{Annual loss of calves by infertility (R\$)}

Number of dead newborns from infected cows

Calves loss in 14 months

Calves loss in 12 months

Annual losses by death of newborns (R\$)

Reduction in the number of calves due to dilation of the calving interval for 345.3 cows

Calves loss in 14 months

$0-45.8$

0-11,908.00

0-10.7 Table 1 and Table 3

$0-10.7$

$0-9.2$

0-2,392.00

0-53.4 Table 1 and Table 3

$1-53.4$

$1-45.8$

0-11,908.00

Table 1 and Table 3

$1-103.6$

$1-88.8$

0-23,088.00

Annual loss of calves by infertility (R\$)

Value

DEATH OF ANIMALS

Variable

Number of cows that miscarried

Number of cows that died after abortion

1-53.4 Table 1 and Table 3

Average price of adult mestizo cow

Annual losses for death of cows after abortion (R\$)

$1-0.53$

390

0-207.23

${ }^{1}$ prices for the state of São Paulo accessed on 08/25/2003

2 provided by the veterinary doctor in the SIF in SP, 2003

${ }^{3}$ proportional estimate of the price/arroba was made in accordance with the price/head of adult bovine animals consulted

* Equivalent to approx. $15 \mathrm{~kg}$ live weight.

Table 5. The actual prevalence of bovine tuberculosis for the municipality of Pirassununga in 2001 (HOMEM, 2003).

\begin{tabular}{lcc}
\hline \multicolumn{1}{c}{ Actual prevalence } & Lower limit CI & Upper limit CI \\
\hline PER PROPERTY & & 66.5 \\
percentage & 44.7 & 499 \\
absolute number & 335 & \\
PER ANIMAL & & 12.3 \\
percentage & 5.5 & 2054 \\
absolute number & 919 & 1623 \\
number of cows $(79 \%)^{1}$ & 726 & 431 \\
number of bulls $(21 \%)^{2}$ & 193 & \\
\hline
\end{tabular}

${ }^{1}$ average age of positive cows $=5$ years and 6 months

${ }^{2}$ average age of positive bulls $=2$ years and 8 months. 
Table 6. Production parameters for the estimation of the impact of bovine tuberculosis in the municipality of Pirassununga in 2001-03.

\begin{tabular}{lcll}
\hline \multicolumn{1}{c}{ Variable } & Value & Reference \\
\hline Milk & & \\
\hline $\begin{array}{l}\text { Average daily production (liters) / number of cows of positive } \\
\text { herds }\end{array}$ & 3.2 & Database \\
$\begin{array}{l}\text { Average daily production (liters) / number of cows of supposed } \\
\text { negative herd }\end{array}$ & 3.9 & Table 1 \\
$\begin{array}{l}\text { Price per liter of C milk (R\$) } \\
\text { Liters of milk/cow/year loss }\end{array}$ & 0.50 & http://www.milkpoint.com.br ${ }^{1}$ \\
Loss per cow/year (R\$) & $\mathbf{1 2 8 . 0 0}$ & \\
\hline MEAT & & \\
\hline Estme of & & \\
\hline
\end{tabular}

Estimate of the weight (arrobas) of infected bovine carcass by sex and age (1) :

Mestizo bull (2 years and 8 months)

15 Verbal information ${ }^{2}$

Mestizo cow (5.5 years)

$13 \quad$ Verbal information ${ }^{2}$

Estimate of the price of arroba of beef by age and sex

Male mestizo (2 years and 8 months) $(\mathrm{R} \$)$

$45.00 \quad$ http://www.beefpoint.com.br ${ }^{1,3}$

Female mestizo (5.5 years) (R\$) 35.00

Weight loss in arrobas due to infection

Bull

$2.93 \quad$ Table 1

Cow

2.53

Table 1

Loss per bull/year (R\$)

$\mathbf{1 3 2 . 0 0}$

Loss per cow/year (R\$)

88.70

\begin{tabular}{lcl}
\hline Variable & Value & Reference \\
\hline Fertility (p= 726-1623 infected cows) & & \\
\hline Average price of male and female calf (R\$) & 260.00 & http://www.beefpoint.com.br ${ }^{1}$ \\
Number of newborn deaths, born from infected cows & $7.3-16.2$ & Table 1 and Table 5 \\
Calves less in 14 months & $7.3-16.2$ & \\
Calves less in 12 months & $6.3-13.9$ & \\
\hline
\end{tabular}

Annual losses for death of newborns (R\$)

1,638.00-3,614.00

Infected cows which have become infertile

$36.3-81.2$

Table 1 and Table 5

Calves loss by infertility in 14 months

$36.3-81.2$

Calves loss by infertility in 12 months

$31.1-69.6$

Annual loss of calves by infertility (R\$) $\quad \mathbf{8 , 0 8 6 . 0 0 - 1 8 , 0 9 6 . 0 0}$

${ }^{1}$ available online on $08 / 25 / 2003$

2 provided by the veterinary doctor in the SIF in SP, 2003

${ }^{3}$ The proportional estimate of the price/arroba was made in accordance with the price/head of adult bovine animals consulted.

Tables 7 and 8 list the minimum and maximum annual financial losses caused by the two diseases in the municipality. The estimated annual economic impact of brucellosis reached R \$ 132,676.23 (Table 7), which was lower compared to tuberculosis, which ranged from between $\mathrm{R} \$ 192,500.00$ and $\mathrm{R} \$$ 430,252.00 (Table 8). The prevalence of the disease in the animals from brucellosis [0-2.2\%] (Table 3) was significantly less than that for tuberculosis [5.5$12.3 \%$ ] (Table 5). 
Table 7. Minimum and maximum annual financial losses caused by bovine brucellosis in the municipality of Pirassununga in 2003.

\begin{tabular}{|c|c|c|}
\hline \multirow{2}{*}{ Variable } & \multicolumn{2}{|l|}{ Loss $(\mathrm{R} \$)$} \\
\hline & Minimum & Maximum \\
\hline$\overline{\text { Milk }}$ & 0.0 & $64,970.00$ \\
\hline Meat & 0.0 & $18,203.00$ \\
\hline Calves by abortion & 0.0 & $11,908.00$ \\
\hline Calves by infertility & 0.0 & $2,392.00$ \\
\hline Neonatal death & 0.0 & $11,908.00$ \\
\hline Calves by extension of the calving interval & 0.0 & $23,088.00$ \\
\hline Death of cows after abortion & 0.0 & 207.23 \\
\hline TOTAL & 0.0 & $132,676.23$ \\
\hline
\end{tabular}

Basis of calculation: prevalence in animals $=0$ to 367 ; prevalence in cows $=0$ to 356 ; prevalence in bulls $=0$ to 11 .

Table 8. Minimum and maximum financial losses caused by bovine tuberculosis in the municipality of Pirassununga in 2003 .

\begin{tabular}{|c|c|c|}
\hline \multirow{2}{*}{ Variable } & \multicolumn{2}{|l|}{ Loss $(\mathrm{R} \$)$} \\
\hline & Minimum & Maximum \\
\hline Milk & $92,928.00$ & $207,744.00$ \\
\hline Meat & $89,848.00$ & $200,798.00$ \\
\hline Calves by infertility & $8,086.00$ & $18,096.00$ \\
\hline Neonatal death & $1,638.00$ & $3,614.00$ \\
\hline TOTAL & $192,500.00$ & $430,252.00$ \\
\hline
\end{tabular}

Basis of calculation: prevalence in animals $=919$ to 2054 ; prevalence in cows $=726$ to 1623 ; prevalence in bulls $=193$ to 431 .

\section{Discussion}

The monetary values which existed in 2003 $(1 / 1 / 2003)$ were converted to comparative values for $2015(1 / 1 / 2015)$ using the General Market Price Index - (IGP-M) (CALCULO EXATO, 2015). The annual economic impact of bovine brucellosis in Pirassununga in 2003 was estimated at $\mathrm{R} \$ 132,676.23$ (value updated by the IGP-M: $\mathrm{R} \$ 273,407.43$ ). The losses from bovine tuberculosis were $\mathrm{R} \$ 192,500.00-\mathrm{R} \$ 430,252.00$ (values updated by the IGP-M: $\mathrm{R} \$ 396,686.97$ to $\mathrm{R} \$ 886,825.25)$. The larger loss caused by tuberculosis was a consequence of its higher prevalence.

The model used in this study did not factor in losses arising from diseases in the human population. Likewise, they did take into account the national and international trade of bovine products. Being a transversal study, it examined results obtained for a given period of time, unlike a longitudinal study, in which the results and information pertaining to a certain period, tracking the effects of control strategies on prevalence in individuals (DIJKHUIZEN; MORRIS, 1997; MARTIN et al., 1994; THRUSFIELD, 1995).

The model proposed here, starting from the actual prevalence of diseases, of production information of the target population, with the addition of productive impact based on literature data and processing this into financial values, allowed for an estimate of the economic impact of bovine brucellosis and tuberculosis in the municipality of Pirassununga. The same model can be used for studies in other regions of Brazil

The results suggest that both brucellosis and tuberculosis have led to significant losses in livestock numbers and their products in Pirassununga. The 
impacts they have on agriculture, and the economy, should be rapidly be communicated throughout Brazil because it will significantly improve the management of veterinary sanitary processes.

\section{Acknowledgements}

We would like to thank Prof. Vitor Salvador Picão Gonçalves of the University of Brasilia for reviewing this manuscript and providing valuable input.

\section{References}

ACHA, P. N.; SZYFRES, B. Zoonosis y enfermidades transmissibles comunes al hombre y a los animales. . (Ed.). Bacteriosis $y$ micosis. $3^{\text {th }}$ ed. Washington: Organização Panamericana de la Salud, 2001. p. 266283. v. 1. (Publicación Científica, 580).

BARWINEK, F.; TAYLOR, N. M. Assessment of the socio-economic importance of bovine tuberculosis in Turkey and possible strategies for control or eradication. Turkish - German animal health information project. General directorate of protection and control akay cad. Ankara: Bakanliklar, 1996. n. 3, 113 p.

BENNETT, R. M. The use of economic quantitative modeling techniques in livestock health and diseasecontrol decision making: a review. Preventive Veterinary Medicine, Atlanta, v. 13, p. 63-76, 1992.

BERNUÉS, A.; MANRIQUE, E.; MAZA, M. T. Economic evaluation of bovine brucellosis and tuberculosis eradication programmes in a mountain area of Spain. Preventive Veterinary Medicine, Atlanta, v. 30, p. 137-149, 1997.

BRASIL. Ministério da Agricultura, Pecuária e Abastecimento, MAPA. Secretaria de Defesa Agropecuária. Instrução Normativa Ministerial no 2/2001 - Institui o Programa Nacional de Controle e Erradicação da Brucelose e Tuberculose Animal. Brasília: Ministério da Agricultura, Pecuária e Abastecimento, 2001.

Gabinete do Ministro. Portaria Ministerial $n^{\circ}$ 23/1976. Aprova as Normas de Profilaxia da Brucelose Animal. Brasília: [s.n.], 1976. Disponível em: $\quad<$ http://sistemasweb.agricultura.gov.br/sislegis/ action/detalhaAto.o? method=consultarLegislacaoFeder al>. Acesso em: 20 maio 2015.
Secretaria de Defesa Agropecuária. Departamento de Inspeção de Produtos de Origem Animal. Regulamento de Inspeção Industrial e Sanitária de Produtos de Origem Animal. Brasília: Diário Oficial da União, 1952. Disponível em: $<$ http://www.agricultura. gov.br/arq_editor/file/Animal/Mercado Interno/ Requisitos/RegulamentoInspecaoIndustrial.pdf $>$. Acesso em: 20 maio 2015.

CALCULO EXATO. 2015. Available at: <http:// calculoexato.com.br/parprima.aspx?codMenu=Finan AtualizaIndice>. Access at: 24 sept. 2015.

DIJKHUIZEN, A. A.; MORRIS, R. S. Animal health economics: principles and applications. Sydney: University of Sydney, 1997. 305 p.

HOEDEMAKER, M. The management of reproduction in high producing dairy cows. Revista Brasileira de Reprodução Animal, Belo Horizonte, v. 21, n. 3, p. 7781, 1997.

HOMEM, V. S. F. Brucelose e tuberculose bovinas no município de Pirassununga, SP: prevalências, fatores de risco e estudo econômico. 2003. Tese (Doutorado em Medicina Veterinária) - Faculdade de Medicina Veterinária e Zootecnia, Universidade de São Paulo, São Paulo.

INSTITUTO BRASILEIRO DE GEOGRAFIA E ESTATÍSTICA - IBGE. Cidades @. Estado de São Paulo. Pirassununga: [s.n.], 1999. Disponível em: <http://www. cidades.ibge.gov.br/>. Acesso em: 23 abr. 2003.

.Cidades@. Estado de São Paulo. Pirassununga: [s.n.], 2010. Disponível em: <http://www.cidades. ibge.gov.br/xtras/perfil.php?lang=\& codmun=353930>. Acesso em: 25 maio 2015.

Sistema de Recuperação Automática - SIDRA. Pesquisa Pecuária Municipal. Pitassununga: [s.n.], 2001. Disponível em: <http://www.sidra.ibge.gov.br/bda/ tabela/protabl.asp? $\mathrm{z}=\mathrm{t \& o}=12>$. Acesso em: 23 abr. 2003.

KANTOR, I. N.; RITACCO, V. Bovine tuberculosis in Latin America and the Caribbean current status, control and eradication programs. Veterinary Microbiology, Atlanta, v. 40, n. 1-2, p. 5-14, 1994.

MARTIN, S. W.; MEEK, A. H.; WILlEBERG, P. Veterinary epidemiology: principles and methods. $4^{\text {th }}$ ed. Ames: Iowa State University Press, 1994. 343 p.

MELO, L. E. H. Avaliação da intercorrência entre leucose enzoótica, tuberculose e leptospirose dos bovinos em rebanhos produtores de leite C do Estado de São Paulo. 1999. Tese (Doutorado em Medicina Veterinária) - Faculdade de Medicina Veterinária e Zootecnia. Universidade de São Paulo, São Paulo. 
NGATEGIZE, P. K.; KANEENE, J. B. Evaluation of the economic impact of animal diseases on production: a review. Veterinary Bulletin, Oxfordshire, v. 55, n. 3, p. 153-162, 1985.

PAULIN, L.; FERREIRA NETO, J. S. O combate à brucelose bovina: situação brasileira. Jaboticabal: FUNEP, 2003. $154 \mathrm{p}$.

SÃO PAULO. Secretaria da Agricultura e Abastecimento do Estado de São Paulo. Projeto LUPA. São Paulo: Secretaria de Agricultura e Abastecimento do Estado de São Paulo, 1996.
THRUSFIELD, M. Veterinary epidemiology. $2^{\text {th }}$ ed. Cambridge: The University Press, 1995. 479 p.

WORLD HEALTH ORGANIZATION - WHO. Bacterial and viral zoonosis. Technical report series. Genebra: World Health Organization, 1982. n. 682, 146 p. 